Vidal, G. 1976b: Late Precambrian acritarchs from the Eleonore Bay Group and Tillite Group in East Greenland. Rapp. Grønlands geol. Unders. 78, 19 pp.

Vidal, G. 1979a: Acritarchs and the correlation of the Upper Proterozoic. Publ. Inst. Mineral. Palaeont. Quat. Geol. Univ. Lund 219, 22 pp.

Vidal, G. 1979b: Acritarchs from the Upper Proterozoic and Lower Cambrian of East Greenland. Bull. Grønlands geol. Unders. 134, $40 \mathrm{pp}$.

Vidal, G. 1981a: Micropalaeontology and biostratigraphy of the Upper Proterozoic and Lower Cambrian sequence in East Finnmark, northern Norway. Bull. Nor. geol. Unders. 362, 53 pp.

Vidal, G. 1981b: Aspects of problematic acid-resistant, organic-walled microfossils (acritarchs) in the Upper Proterozoic of the North Atlantic region. Precambrian Res. 15, 9-23.

Vidal, G. \& Dawes, P. R. 1980: Acritarchs from the Proterozoic Thule Group, North-West Greenland. Rapp. Grønlands geol. Unders. 100, 24-29.

Vidal, G. \& Knoll, A. H. 1983: Proterozoic plankton. Mem. Geol. Soc. Amer. 161, 265-277.

Vidal, G. \& Siedlecka, A. 1983: Planktonic, acid-resistant microfossils from the Upper Proterozoic strata of the Barents Sea region of Varanger Peninsula, East Finnmark, Northern Norway. Bull. Nor. geol. Unders. 382, 45-79.

G.V., Dept. of Historical Geology and Palaeontology,

\title{
Fission track dating of lower Tertiary rhyolitic glass rocks from Disko
}

\author{
Kirsten Hansen and Asger Ken Pedersen
}

\section{Geology and stratigraphy}

The Tertiary igneous activity in West Greenland has not been dated in detail. Sediments contemporaneous with, or slightly older than, the early volcanic rocks are assigned a middle Paleocene age from palaeontological evidence (Henderson et al., 1981), and palaeomagnetic work by Athavale \& Sharma (1975) indicates that the Vaigat Formation picrites and the lower $500 \mathrm{~m}$ or so of the overlying Maligât Formation (Hald \& Pedersen, 1975) were erupted in the time span represented by geomagnetic anomaly 25 together with the long reversal period between anomalies 25 and 24. The age estimated for this period is 56 to $52 \mathrm{Ma}$ (Butler \& Coney, 1981). The late Stage lamprophyre magmatism on Ubekendt Ejland appears to be much younger, about 30 to $40 \mathrm{Ma}$ (Parrott \& Reynolds, 1975). No reliable radiometric age determinations have been published from the Disko-Nûgssuaq area.

In order to date the younger part of the basalt succession on Disko, zircons were separated from three blocks of garnet-bearing peraluminous rhyolite glass from a conglomerate 
Table 1. Fission track ages for zircons from rhyolitic glass rocks from Disko

\begin{tabular}{lcccc}
\hline Sample no. & $\begin{array}{c}\text { no. of } \\
\text { crystals }\end{array}$ & $\begin{array}{c}\mathrm{g}_{s}\left(\mathrm{~N}_{\mathrm{s}}\right) \\
\left(\mathrm{X} 10^{7}\right)\end{array}$ & $\begin{array}{c}\mathrm{g}_{\mathrm{i}}\left(\mathrm{N}_{\mathrm{i}}\right) \\
\left(\mathrm{X} 10^{7}\right)\end{array}$ & $\begin{array}{c}\text { Age Ma } \\
1 \text { sigma errors }\end{array}$ \\
\hline 156558 & 6 & $0.7776(425)$ & $0.3659(200)$ & $43.6 \pm 3.9$ \\
156518 & 4 & $0.3378(140)$ & $0.1665(69)$ & $41.6 \pm 6.2$ \\
156516 & 10 & $0.7263(554)$ & $0.3212(245)$ & $46.4 \pm 3.7$ \\
All samples & 20 & $0.6492(1119)$ & $0.2982(514)$ & $44.6 \pm 2.6$ \\
\hline
\end{tabular}

$\varrho_{s}$ is the track density for spontaneous tracks, $N_{s}$ the total number of spontaneous tracks counted, $\varrho_{i}$ the track density for induced tracks and $\mathrm{N}_{\mathrm{i}}$ the total number of induced tracks counted. The error is calculated from the statistical counting error and the standard error of the mean for the calibration constants. Location: 156558 : $70^{\circ} 04^{\prime} 70^{\prime \prime} \mathrm{N}, 54^{\circ} 44^{\prime} 30^{\prime \prime} \mathrm{W} ; 156518$ and 156516: $70^{\circ} 07^{\prime} 40^{\prime} \mathrm{N}, 54^{\circ} 46^{\prime} 40^{\prime} \mathrm{W}$.

horizon in the Nordfjord Member of the upper Maligât Formation (Pedersen, 1975, 1977) in north-west Disko. The localities from which the glass blocks were selected show evidence of only low zeolite facies metarmophism.

\section{The fission track dating method}

Separated zircons were mounted and etched according to the suggestions of Gleadow et al. (1976). The mounts were covered with a muscovite sheet as an external detector (Gleadow \& Lovering, 1978) and irradiated in the J1 facility of the Herald reactor, Aldermaston, U.K. The Fish Canyon zircon was used as an age standard for the calibration (Hurford \& Green 1983). Annealing temperatures for zircons are not well established, but new investigations show that zircons are likely to anneal only at temperatures above $200^{\circ} \mathrm{C}\left(\mathrm{c} .225^{\circ} \mathrm{C}\right)$ for geological time spans (Hurford, 1984). This is far above the temperatures that the glass blocks and their associated tuff sediments have experienced, and fission tracks should hence date the initial cooling of the volcanic host rocks. Three age determinations are reported in Table 1. Since the ages cannot be separated statistically, an overall age has been calculated as $44.6 \pm 2.6 \mathrm{Ma}$, which corresponds to the lower Eocene.

\section{Implications}

The fact that the age of the rhyolitic rocks from the Nordfjord Member in the upper part of the basalt pile is about $45 \mathrm{Ma}$, compared with the much oder ages (56-52 Ma) for the lower part of the basalts, indicates that the volcanism in the Disko-Nûgssuaq area did not occur as a single major volcanic cycle. Widespread small conglomerate horizons occur in the Nordfjord Member, and it can be demonstrated that hundreds of metres of plateau basalts have been eroded away locally. This points to a significant and prolonged decline in the magmatic activity with time. A consequence of the reported Eocene age is that volcanic rocks which could record parts of the magnetic anomalies 24 to 20 (Butler \& Coney, 1981) may be present in the upper part of the Maligât Formation on Disko which has not yet been measured palaeomagnetically. 
Acknowledgements. This work was supported by the Danish Natural Science Research Council.

\title{
References
}

Athavale, R. N. \& Sharma, P. V. 1975: Palaeomagnetic results on early Tertiary lava flows from West Greenland and their bearing on the evolution history of the Baffin Bay - Labrador Sea region. Can.J. Earth Sci. 12, 1-18.

Butler, R. F. \& Coney, P. J. 1981: A revised magnetic polarity time scale for the Paleocene and early Eocene and implications for Pacific plate motion. Geophys. Res. Lett. Washington 8, 301-304.

Gleadow, A. J. W. \& Lovering, J. F. 1978: Thermal histories of granitic rocks from Western Victoria: a fission track dating study. J. geol. Soc. Aust. 25, 323-340.

Gleadow, A. J. W., Hurford, A. J. \& Quaife, R. 1976: Fission track dating of zircons: improved etching techniques. Earth planet. Sci. Lett. 33, 273-276.

Hald, N. \& Pedersen, A. K. 1975: Lithostratigraphy of the early Tertiary volcanic rocks of central West Greenland. Rapp. Grønlands geol. Unders. 69, 17-24.

Henderson, G., Schiener, E. J., Risum, J. B., Croxton, C. A. \& Andersen, B. B. 1981: The West Greenland basin In Kerr, J. W. \& Ferguson, A. J. (edit.) Geology of the North Atlantic borderlands. Mem. Can. Soc. Petrol. Geol. 7, 399-429.

Hurford, A. J. 1984: On the closure temperature for fission tracks in zircon. 4th International Fission Track Dating Workshop, July 31-August 3, 1984, Troy, New York, Abstracts.

Hurford, A. J. \& Green, P. 1983: The Zeta age calibration of fission trace dating. Isotope Geosci. 1, 285-317.

Parrott, R. J. E. \& Reynolds, P. H. 1975: Argon 40/argon 39 geochronology: age determinations of basalts from the Labrador Sea area. Abstr. geol. Soc. Am. 7, 835.

Pedersen, A. K. 1975: New mapping in north-western Disko, 1972. Rapp. Grønlands geol. Unders. 69, 25-32.

Pedersen, A. K. 1977: Iron-bearing and related vocanic rocks in the area between Gieseckes Dal and Hammers Dal, north-west Disko. Rapp. Grønlands geol. Unders. 81, 5-14.

K. $H$,

Institut for Petrologi,

$\emptyset$ ster Voldgade 10,

1350-Copenhagen $K$.
A. K. $P$.,

Geologisk Museum,

Øster Voldgade 5-7, 1350-Copenhagen $K$.

\section{Ordovician(?) gastropods from cherts in Cretaceous sandstones, south-east Disko, central West Greenland}

\author{
Asger Ken Pedersen and John S. Peel
}

Field work by AKP during 1984 on south-east Disko included a brief re-investigation of an unusual assemblage of clasts found in the Upper Cretaceous sandstones of the Atane Formation. These clasts were first found by Giesecke in 1807 (Giesecke, 1910) and subsequently briefly characterised by Schiener (1974, p. 25) as "a characteristic marker assemblage of ex- 